Mihailo Mrdak ${ }^{*}$, Časlav Lačnjevac ${ }^{2}$, Marko Rakin $^{3}$, Nikola Bajić ${ }^{4}$

${ }^{1}$ Research and Development Center, IMTEL Communications a.d., Belgrade, Serbia, ${ }^{2}$ University of Belgrade, Faculty of Agriculture, Belgrade, Serbia, ${ }^{3}$ University of Belgrade, Faculty of Technology and Metallurgy, Belgrade, Serbia, ${ }^{4}$ Techno experts d.o.o - Research and Development Center, IHIS, Belgrade, Serbia
Scientific paper

ISSN 0351-9465, E-ISSN 2466-2585

UDC:669.294.86

doi:10.5937/zasmat1804489M

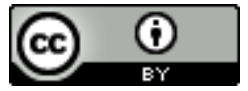

Zastita Materijala 59 (4)

489 - 494 (2018)

\title{
Characterization of tantalum coatings deposited using vacuum plasma spray process
}

\begin{abstract}
Tantalum is a very popular material for the industry as a whole because of very important characteristics such as: high melting point, significant thermal and electrical conductivity, high toughness and resistance to corrosion and good biocompatibility. Since the tantalum metal is sensitive to $\mathrm{O}, \mathrm{N}$ and $\mathrm{H}$ gases, tantalum coating layers are deposited only using the vacuum plasma spray process (VPS), which has, in the past few years been used successfully for preparing coatings which are widely used in the preparation of metal implants.

The aim of this paper was to, at a low pressure inert gas eliminate the influence of the surrounding atmosphere on the melted Ta powder particles and produce coatings with mechanical and structural characteristics which will find application in biomedicine. For depositing the coating a commercial tantalum powder AMPERIT® 151065 grain size of $10-30 \mu \mathrm{m}$ was used. The powder was deposited with a plasma F4 gun at a distance of substrates at $300 \mathrm{~mm}$. The Ta coating layers were deposited with a thickness of 60 to $70 \mu \mathrm{m}$ on steel substrates. As the plasma gas used was a mixture of Ar and He inert gases.

The microhardness of the coating was tested using the $H V_{0.3}$ method and the tensile strength of the coatings bond was tested by the tensile method in accordance with the ASTM C633-1 standard. The microstructure of the coating in deposited state and after etching was studied on an optical microscope (OM) and scanning electron microscope (SEM). Etching the coating was carried out in the reagent which consisted of two parts of nitric acid, two parts hydrofluoric acid, and five parts water $\left(2 \mathrm{HNO}_{3}: 2 \mathrm{HF}: 5 \mathrm{H}_{2} \mathrm{O}\right)$. The structure of the coating consists solely of a tough $\alpha$ Ta phase with a body centered cubic lattice. Tests have shown that layers of VPS - Ta coatings have the microstructure and mechanical properties which completely support the use of the coating in the process of making implants.
\end{abstract}

Keywords: tantalum coating, mechanical properties, vacuum, microhardness, phases, characteristics, strength.

\section{INTRODUCTION}

Vacuum Plasma Spray (VPS) or low pressure plasma spray (LPPS) processes are good choices for the deposition of high quality coatings. These systems produce coatings which have great advantages because of their performance in comparison to the coatings produced by other industrial processes [1].

${ }^{*}$ Corresponding autor: Mihailo Mrdak

E-mail: drmrdakmihailo@gmail.com

Paper received: 10. 07. 2018.

Paper accepted: 05. 08. 2018.

Paper is available on the website: www.idk.org.rs/casopis
High performance is achieved by providing a deposit which hashigh tensile bond strength, with very low levels of porosity and oxides. A high quality coating is achieved by placing the plasma gun in a vacuum chamber at a reduced pressure between 50-200 mbar [2]. The vacuum plasma spray process is used to produce coatings that are resistant to oxidation, hot corrosion and for deposition of heavy metals with a high melting point such as $\mathrm{W}, \mathrm{Ta}, \mathrm{Nb}, \mathrm{Ti}$ and other metals which are cross-reactive to the gases $\mathrm{O}, \mathrm{N}$, and $\mathrm{H}$. This process is very suitable for producing high quality reactive tantalum coatings. The coatings must be homogeneous, of high purity and adhesion. Therefore, the process parameters must be carefully optimized because they are in direct relation with the spray powder, its particle size and 
morphology. The VPS equipment used for the deposition of powder must achieve a final pressure of $10^{-3} \mathrm{mbar}$ for chamber degassing to facilitate cleaning and pre-heating of the substrate with a transferred arc. Also, for the vacuum plasma spray process it is necessary to use powders of high purity with low gas content. For the deposition of tantalum powder inert gasesare exclusively used. Hydrogen as the secondary gas is damaging to tantalum because it forms hydride compounds which cause brittleness of the coating. Tantalum coatings are always deposited in a protective atmosphere at low pressure or in argon shielding, with vigorous cooling of melted powder particles. Intensive cooling during powder deposition prevents the formation of the $\beta$-Ta phase with a tetragonal crystal lattice, which is harder and more brittle than the $\alpha$-Ta phase. The $\beta$-Ta phase reduces the toughness of the coating and has a reduced resistance to corrosion. That is why the deposition of the powder is done with a vigorous cooling rate of melted particles beyond the critical temperature of $\alpha \leftrightarrow \beta$ phase transformation to retain the starting $\alpha-T a$ phasein the structure. In the structure of the coating dominant should only be the $\alpha$-Ta phase with a body centered cubic structure $[3,4]$. Tantalum is a heavy metal having a density of $16.6 \mathrm{~g} / \mathrm{cm}^{3}$. It is characterized by very good corrosion resistance in many hostile environments, and has found wide use as a potential material for medical implants. Today tantalum is used in medical practice, as it demonstrated good biocompatibility and safety of medical implants and prosthetic materials in dentistry $[5,6]$. It is believed that tantalum is a potential biomaterial because it has excellent chemical stability, resistance to body fluids, and biocompatibility and biological binding with bone tissue $[7,8,9]$. Tantalum although attracting more attention for its excellent corrosion resistance and biocompatibility, because of its significantly high modulus of elasticity and high mechanical incompatibility with bone tissue makes it unfit for bearing implants. Depositing the Ta powder using the VPS process, the layers of the porous coating on the surface of the implant provide its medical use [10]. The porous Ta coatings offer low modules of elasticity, high surface friction characteristics, biological activity and biocompatibility $[11,12]$. However, the relatively high cost and difficulty in processing in an inert atmosphere, difficulty of honing and a high melting point limit a wide applicationof $\mathrm{Ta}$ in medical practice [9]. For creating $\mathrm{Ta}$ coatings most commonly used are spherical powder grains, $10-30 \mu \mathrm{m}$ in size. One of the well-known manufacturers of the powder is AMPERIT® which produces powder with the specification 151.065. This powder, apart from biomedical applications is successfully applied for protection against corrosion from sulfuric acid and protection of chemistry equipment against acids. Mechanical properties of the coating the microhardness and tensile bond strength are directly related to the powder deposition parameters.

In this paper, vacuum plasma spray (VPS) process was used for the first time to deposit layers of the Ta coating on stainless steel surfaces. The aim of the paper was to, by using vacuum plasma spray coating technology, deposit a Ta coating of good quality that will find application on biomedical implants and in corrosion aggressive environments. In the process of deposition avoided was the influence of oxygen, nitrogen and hydrogen on the molten $\mathrm{Ta}$ particles, which was confirmed in mechanical and metallographic examinations of the coatinglayers. Based on analysis given was an estimate of the quality of the Ta coating as a potential candidate for use on implants made of stainless steel.

\section{EXSPERIMENTAL PART}

\subsection{Materials and experimental details of plasma spray coatings deposition}

For depositing coating layers of tantalum (Ta) used was the powder AMPERIT® a commercial powder of spherical shape with the specification 151.065. and a granulation of $10-30 \mu \mathrm{m}$. The melting temperature of the powder is $3017^{\circ} \mathrm{C}$.

The samples on which layers of Ta coating were deposited for testing of microhardness and microstructure evaluation were made of steel C. 4171 (X15Cr13 EN10027) in thermally untreated condition, $70 \times 20 \times 1.5 \mathrm{~mm}$ in size, and for tensile bond strength teststhe samples were $\varnothing 25 \times 50 \mathrm{~mm}$ in size in accordance with ASTM C633-1 [13]. Examinations of mechanical and microstructural characteristics of tantalum coating layers were also conducted according to ASTM C633-1 standard [13]. Microhardness testing of the coatingwas done using the $\mathrm{HV}_{0.3}$ methodand tensile bond strength by tensile testing. Microhardness testing was carried out in the direction along the lamellae, in the middle and at the ends of the sample. Five readings were done at three measuring locations, and this paper shows the mean value of microhardness. The method used for bond strength testing is the tension method. Testing was done at room temperature with tensile speed of $10 \mathrm{~mm} / \mathrm{min}$. Fives pecimens were used for testing and this paper shows the mean value. The coating bond strength $\sigma=F / A(\mathrm{MPa})$ is calculated as the maximum load $\left(F_{\max }\right)$ on the sample divided by the area $(A)$ of the coating fracture [14]

Analysis of the share of micropores in the coating was done by examining 5 photos at 200X 
magnification. The paper shows the mean value of the share of micropores. The microstructural analysis of the coating in deposited state and in the state after etching was performed on an optical microscope (OM) and a scanning electron microscope (SEM). To see the coating microstructure of the deposited layers, etching of the coating was carried out with a reagent which consists of two parts of nitric acid, two parts hydrofluoric acid, and five parts water $\left(2 \mathrm{HNO}_{3}\right.$ : 2HF: $5 \mathrm{H}_{2} \mathrm{O}$ ). The reagent erodesthe $\alpha-T a$ phase which is gray in the structure of the coating, while the $\beta$-Ta phase is not etched and is white in color. The samples were etched for 5 minutes and then cleaned with alcohol and dried.

The deposition of the Ta powder was carried out at low pressureinan inert gas (Ar) in the VPS system of the company Plasma Technik AG. The VPS parameters of Ta powder deposition on the samples are shown in table 1.

\section{Table 1. Parameters deposition powder Ta}

Tabela 1. Parametri depozicije praha Ta

\begin{tabular}{|l|c|c|}
\hline \multirow{2}{*}{ Parameters } & \multicolumn{2}{c|}{ Values } \\
\cline { 2 - 3 } & $\begin{array}{c}\text { Cleaning } \\
\text { arc }\end{array}$ & Spraying \\
\hline Plasma current, I (A) & 500 & 750 \\
\hline Plasma voltage, V (U) & 65 & 74 \\
\hline $\begin{array}{l}\text { Primary plasma gas flow } \\
\text { rate, Ar (I/min) }\end{array}$ & 50 & 45 \\
\hline $\begin{array}{l}\text { Secondary plasma gas flow } \\
\text { rate, He (I/min) }\end{array}$ & 10 & 140 \\
\hline $\begin{array}{l}\text { Carrier gas flow rate, } \\
\text { Ar (I/min) }\end{array}$ & -- & 3 \\
\hline Powder feed rate, (g/min) & -- & 30 \\
\hline Stand-off distance, $(\mathrm{mm})$ & 280 & 300 \\
\hline Chamber pressure, $(\mathrm{mbar})$ & 40 & 100 \\
\hline Nozle diameter, $(\mathrm{mm})$ & 8 & 8 \\
\hline Speed of the gun, $(\mathrm{mm} / \mathrm{s})$ & 15 & 240 \\
\hline
\end{tabular}

For deposition of the powder a plasma gun F4 was used, and as plasma gases argon and helium were used. In order to prevent, in the process of deposition, slow cooling of the molten particles and $\alpha \rightarrow \beta$ phase transformation primary cooling was applied. Primary cooling of melted tantalum particles was conducted with high-purity argon, where high velocity undercooling of the molten particles was done. The argon was supplied through two nozzles that were located on the plasma gun. The powder deposition process includes cleaning of the substrate surface using a transferred arc and powder deposition at low pressure. On the microprocessor robot unit of the VPS system of Plasma Technik AG made wasa program for depositing Ta powder. The program was given specified and time-synchronized parameters of the process: evacuating the chamber, flow of plasma gases, cleaning the substrate using a transferred arc, powder flow, deposition of the coating, cooling of the substrate with the deposited coating and ventilation of the vacuum chamber. Before the deposition of powder roughing of the samples was done with corundum particles size of $0.7-1.5 \mathrm{~mm}$. The coating was deposited with a thickness of $60-70 \mu \mathrm{m}$.

\section{RESULTS AND DISCUSSION}

\subsection{Results of coatings testing}

At the cross section of the Ta coating layers measured was a microhardness mean value of 228 $\mathrm{HV}_{0.3}$. The measured values of the microhardness of the layers of the Ta coating indicate that at lowpressure of an inert $\mathrm{Ar}$ atmosphere and inert plasma gases $\mathrm{Ar} / \mathrm{He}$ it was not possible to form the stable and hard $\mathrm{Ta}_{2} \mathrm{O}_{5}$ oxide, this was confirmed by analysis of the microstructure of the coating layers on the optical microscope (OM) and scanning electron microscope (SEM). Also, the mean value of microhardness indicates that the primary cooling with argon enabled rapid undercooling of the liquid tantalum droplets and forming of the tough $\alpha-\mathrm{Ta}$ phase in the coating, which was confirmed by analysis of the microstructure after etching of the coating layers. Tensile bond strength between the layers of Ta coating and the substrate was $64 \mathrm{MPa}$. Mechanically roughening the surface of the samples and cleaning the surface with a transferred arc enabled good bonding of the deposited particles with the substrate, which resulted in obtaining a high value of tensile bond strength. The destruction of the coating was adhesive at the substrate/coating interface. The values of microhardness and tensile bond strength of the Ta coating layers were consistent with their microstructures. Figure 1 shows the microstructure of the Ta coating layers in deposited state.

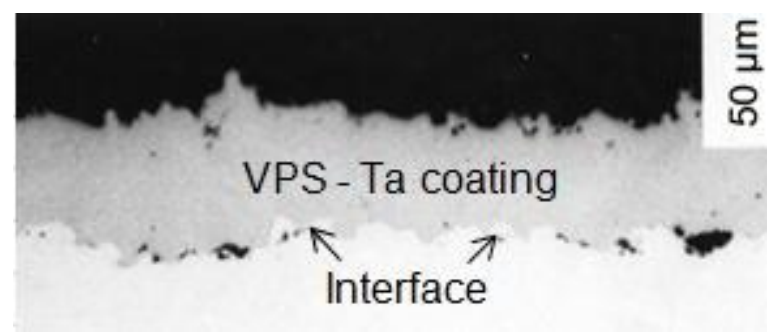

Figure 1. Microstructure of the Ta coating layers in deposited state

\section{Slika 1. Mikrostruktura slojeva prevlake Ta u deponovanom stanju}

Qualitative analysis of the coating layers determined that at the interface of the substrate and the deposited coating there were no present discontinuities of the deposited layers on the 
substrates, no micro and macro cracks, separation of the coating from the base or delamination of the coating. A good connection was achieved between the coating layers and the substrate surface. Due to a good cohesive connection between the deposited powder particles, through the coating layers there are no observed inter-lamellar boundaries. In the microstructure of the Ta coating there are no gray $\mathrm{Ta}_{2} \mathrm{O}_{5}$ oxide lamellae, which confirms that the use of plasma gases $\mathrm{Ar} / \mathrm{He}$ at a low pressure of the inert $\mathrm{Ar}$ gas in a vacuum chamber eliminated oxidation of melted Ta powder particles. The share of micropores in the deposited coating layers was below 1\%. Figures 2 and 3 show the microstructure of the vacuum plasma spray Ta coating in etched state.

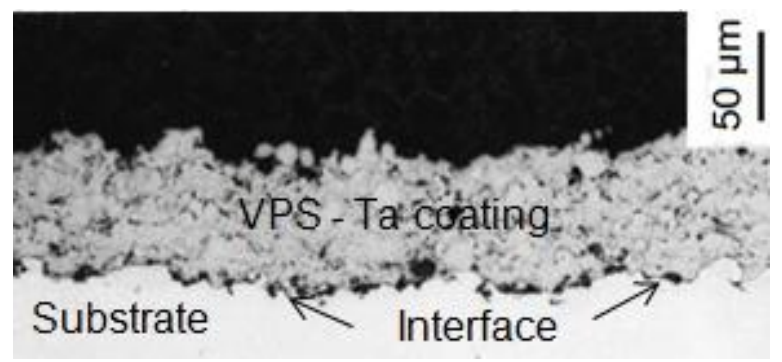

Figure 2. Microstructure of Ta coatings in etched state

Slika 2. Mikrostruktura Ta prevlake u nagrizenom stanju

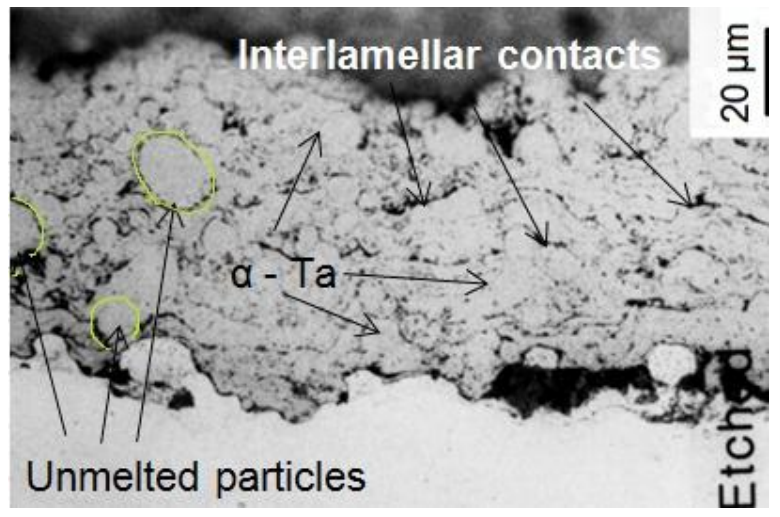

Figure 3. Microstructure of Ta coatings in etched state

Slika 3. Mikrostruktura Ta prevlake u nagrizenom stanju

After etching the coating layers, inter-lamellar boundaries appeared in the microstructure and are marked by arrows. The structure of the coating consists of well melted and properly deformed powder particles, semi-melted particles, and unmelted particles marked with arrows. Unmelted powder particles that are visible in the microstructure of the coating layers, circled green confirm that the powder used for deposition was of spherical morphology. The reagent $2 \mathrm{HNO}_{3}$ : $2 \mathrm{HF}$ : $5 \mathrm{H}_{2} \mathrm{O}$ erodes the $\alpha-\mathrm{Ta}$ phase and inter-lamellar boundaries whic hare cities that have the highest concentration of stress in the coating. In the microstructure of the Ta coating clearly can be seen dark gray layers of deposited particles with an $\alpha$ - Ta primary phase.The microstructure of this coating does not show white areas of the brittle $\beta$ phase. The microstructure of the coating suggests that the rapid cooling regime of the powder particles during deposition eliminated the formation of the hard and brittle $\beta$ - phase in the coating layers, which is in accordance with the mechanical properties of the Ta coating layers.

Figures 4 and 5 show SEM micrographs of the Ta coating with lower and higher magnification clearly showing the microstructure of the coatings in deposited state. Figure 4 clearly shows a micropore the size of $10 \mu \mathrm{m}$ and very fine micro-pores at the boundaries of the deposited particles through the coating layers.

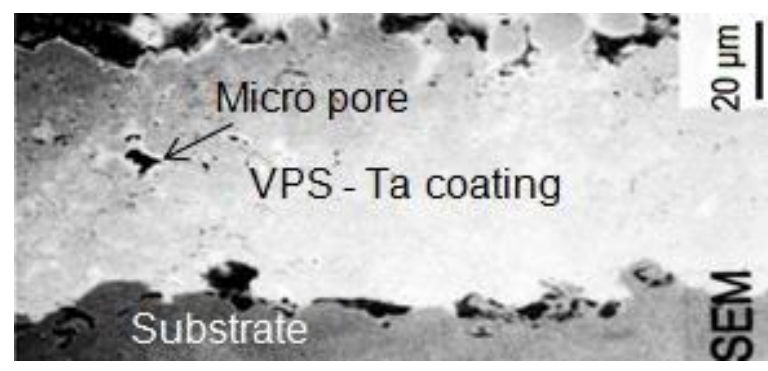

Figure 4. SEM microstructure of Ta coatings in deposited state

Slika 4. SEM mikrostruktura Ta prevlake u deponovanom stanju

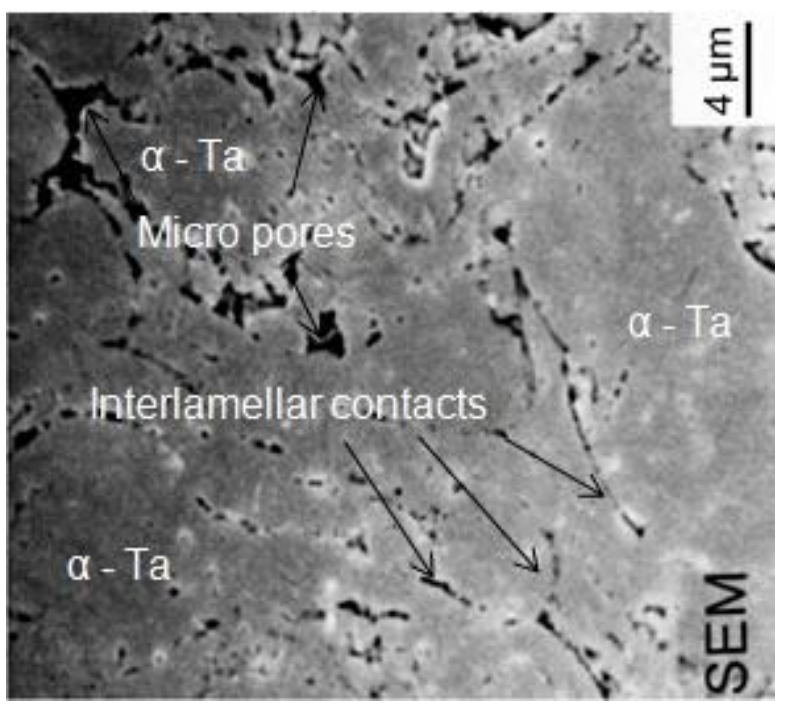

Figure 5. SEM microstructure of Ta coatings in deposited state

Slika 5. SEM mikrostruktura Ta prevlake u deponovanom stanju 
Micropores are clearly visible on micrograph 5 . On the SEM micrograph 5 dark gray areas of the a Ta phase and black inter boundaries marked by arrows can be seen. On the surfaces of the melted and unmelted particles there are no visible oxide layers, confirming that in the process of deposition there was no interaction between the droplets of melted tantalum with the surrounding atmosphere due to good degassing of the vacuum chamber and application of inert gases. In the structure of the coating there are no observed precipitates which result from the collision of molten drops with the substrate and the previously deposited coating. At the moment of collision with the substrate there may be breaking off of ends of the well-melted particles, which in the deposited layers of the coating harden as sediment. Molten particles of tantalum in collision with the substrate overlapped one over the other, forming lamellae and interlamellar small sized pores. Due to the high melting point of the powder and short time spent in the plasma, the particles do not have the same temperature over the cross section. Due to the high plasma temperature the surface of the particles is in liquid state and evaporate while the particles that are under the surface are in molten and semimolten state, and in the core they unmelted with a starting $\alpha$ - Ta phase. The unmelted cores of the powder particles are starting points for nucleation and solidification of the liquid phase by rapid cooling untilforming a coating with an $\alpha-T a$ structure. The basic $\alpha$ - Ta phase of the coating was formed by rapid sub-cooling and quenching of the liquid phase above $750^{\circ} \mathrm{C}$ which is the critical temperature of phase transformation $\alpha \rightarrow \beta$. SEM analysis of the coating confirmed that in the microstructure of the coating there is no white brittle $\beta$-phase present.

\section{CONCLUSIONS}

In this paper, using vacuum plasma spray (VPS) technology layers of tantalum coating were deposited. Analyzed were the mechanical properties of the coating (microhardness and tensile bond strength) and the microstructure in deposited state and the state after the etching in the reagent $2 \mathrm{HNO}_{3}: 2 \mathrm{HF}: 5 \mathrm{H}_{2} \mathrm{O}$, based on which the following conclusions were made.

VPS - Ta coating had a mean value of 228 $\mathrm{HV}_{0.3}$ of microhardness and tensile bond strength of $64 \mathrm{MPa}$. Mechanical roughing and cleaning of the surface of samples by transferred arc allowed better binding of melted powder particles to the substrate, which resulted in obtaining a high value of tensile bond strength. The values of the mechanical properties of coatings were correlated with their microstructures.
The Ta coating microstructure after etching in deposited state was single phase. The microstructure of the coating has a tough gray $\alpha$ Ta phase. The white $\beta$ - Ta phase which is not etched was not observed in the microstructure of the coating. The quantity of micropores was below $1 \%$.

VPS - Ta coating had good mechanical and structural properties, bearing in mind that the goal was to make a Ta coating with improved resistance to different types of damage, for its biomedical applications in the process of making implants.

\section{Acknowledgement}

This investigation was supported by Serbian Ministry of Education, Science and Technological Development (national projects Ol174004 \& TR34016).

\section{REFERENCE}

[1] M.R.Mrdak (2017) Structure and properties of Ni22Cr10Al1Y coatings deposited by the vacuum plasma spray process, Vojnotehnički glasnik/ Military Technical Courier, 65(2), 378-391.

[2] M.R.Mrdak (2016) Monografija: Plazma sprej procesi i svojstva zaštitnih prevlaka, ISBN 978-8689775-00-0, p.20-24.

[3] A.Jiang, T.A.Tyson, L.Axe, J.Phys (2005) The stability of the $\beta$-phase of tantalum: a molecular dynamics study, Journal of Physics: Condensed Matter 17, 1841-1852.

[4] M.Sterling, Lin.Jianliang, M.S.Roberto, D.S.William, J.M.John (2013) The $\beta$ to $\alpha$ phase transition of tantalum coatings deposited by modulated pulsed power magnetron sputtering, Surface \& Coatings Technology 214, .38- 45 .

[5] H.Kato, T.Nakamura, S.Nishiguchi, Y.Matsusue, M.Kobayashi, et al. (2000) Bonding of alkali and heat-treated tantalum implants to bone, Journal of Biomedical Materials Research 53, 28-35.

[6] C.Mas-Moruno, B.Garrido, D.Rodriguez, E.Ruperez , F.J.Gil (2015) Biofunctionalization strategies on tantalum-based materials for osseointegrative applications, Journal of Materials Science: Materials in Medicine, 26(2), 109-116.

[7] WJ.Long, GR.Scuderi (2009) Porous tantalum cones for large metaphyseal tibial defects in revision total knee arthroplasty: a minimum 2-year follow-up, Journal Arthroplasty 24, 1086-1092.

[8] GE.Holt, MJ.Christie, HS.Schwartz (2009) Trabecular metal endoprosthetic limb salvage reconstruction of the lower limb, Journal Arthroplasty, 24(7), 1079-1085.

[9] VK.Balla, S.Bodhak, S.Bose, A.Bandyopadhyay (2010) Porous tantalum structures for bone implants: fabrication, mechanical and in vitro biological properties, Acta Biomater, 6, 3349-3359.

[10] LD.Zardiackas, DE.Parsell, LD.Dillon, DW.Mitchell, LA.Nunnery, et al. (2001) Structure, metallurgy, and mechanical properties of a porous tantalum foam, Journal Biomedical Materials Research, 58, 180187. 
[11] B.R.Levine, S.Sporer, RA.Poggie, C.J.Della Valle, J.J.Jacobs (2006) Experimental and clinical performance of porous tantalum in orthopedic surgery, Biomaterials, 27, 4671-4681.

[12] T.Miyaza, HM.Kim, T.Kokubo, C.Ohtsuki, H.Kato, et al. (2002) Mechanism of bonelike apatite formation on bioactive tantalum metal in a simulated body fluid, Biomaterials, 23, 827-832.

[13] ASTM C633-1 (2008) Standard Test Method for Adhesion or Cohesion Strength of Thermal Spray Coatings, Reapproved.
[14] M.Mrdak, N.Bajić, D.Veljić, M.Rakin, J.Pekez, Z.Karastojković (2016) Testing adhesive bond strength and fracture mechanisms of thicker and porous plasma spray coatings, VI International Conference Industrial Engineering and Environmental Protection 2016 (IIZS 2016), University of Novi Sad, Technical faculty "Mihajlo Pupin" Zrenjanin, p.249-253.

\section{IZVOD}

\section{KARAKTERIZACIJA TANTAL PREVLAKE DEPONOVANE VAKUUM PLAZMA SPREJ PROCESOM}

Tantal je veoma atraktivan materijal za industriju u celini zbog veoma bitnih osobina kao što su: visoka temperatura topljenja, značajna toplotna $i$ električna provodljivost, visoka žilavost $i$ otpornost na koroziju i dobra biokompatibilnost. Pošto je tantal metal osetljiv na gasove O, $\mathrm{N} \mathrm{i} \mathrm{H,}$ slojevi prevlake tantala se isključivo deponuju vakuum plazma sprej procesom (VPS), koji se u poslednjih nekoliko godina uspešno koristi za izradu prevlaka koje imaju široku primenu u izradi metalnih implanata.

Cilj rada bio je da se na niskom pritisku inertnog gasa eliminiše uticaj okolne atmosfere na istopljene čestice praha Ta i proizvedu prevlake mehaničkih i strukturnih karakteristika koje će naći primenu u biomedicini. Za deponovanje prevlake koristio se komercijalni prah tantala AMPERIT@ 151.065 granulacije od 10 - 30 um. Prah je deponovan sa plazma pištoljem F4 na odstojanju podloge od $300 \mathrm{~mm}$. Slojevi Ta prevlaka su deponovani sa debljinom od 60 do $70 \mu \mathrm{m}$ na čeličnim podlogama. Kao plazma gas koristila se mešavina inertnih gasova Ar i He.

Mikrotvrdoća prevlake ispitana je metodom $\mathrm{HV}_{0.3}$ a zatezna čvrstoća spoja prevlake ispitana je metodom na zatezanje u skladu sa standardom ASTM C633-1. Mikrostruktura prevlake u deponovnom stanju i u stanju posle nagrizanja ispitana je na optičkom mikroskopu (OM) i na skening elektronskom mikroskopu (SEM). Nagrizanje prevlake sprovedeno je u reagensu koji se sastojao od dva dela azotne kiseline, dva dela fluorovodonične kiseline i pet delova vode $\left(2 \mathrm{HNO}_{3}\right.$ : $2 \mathrm{HF}$ : $5 \mathrm{H}_{2} \mathrm{O}$ ). Struktura prevlake se isključivo sastoji od žilave $\alpha$-Ta faze sa zapreminski centriranom kubnom rešetkom. Ispitivanja su pokazala da slojevi VPS - Ta prevlake imaju mikrostrukturu i mehaničke karakteristike koje u potpunosti omogućavaju primenu prevlake u procesu izrade implanata.

Ključne reči: tantal, prevlaka, mehanička svojstva, vakuum, mikrotvrdoća, faze, svojstva, čvrstoća.

\section{Naučni rad}

Rad primljen: 10. 07. 2018.

Rad prihvaćen: 05. 08. 2018.

Rad je dostupan na sajtu: www.idk.org.rs/journal

\footnotetext{
(c) 2018 Authors. Published by Inženjersko društvo za koroziju. This article is an open access article distributed under the terms and conditions of the Creative Commons Attribution 4.0 International license (https://creativecommons.org/licenses/by/4.0/)
} 